\title{
MORAL PSYCHOLOGY AS A NECESSARY BRIDGE BETWEEN SOCIAL COGNITION AND LAW
}

James P. Dunlea and Larisa Heiphetz

Columbia University

Coordinating competing interests can be difficult. Because law regulates human behavior, it is a candidate mechanism for creating coordination in the face of societal disagreement. We argue that findings from moral psychology are necessary to understand why law can effectively resolve cooccurring conflicts related to punishment and group membership. First, we discuss heterogeneity in punitive thought, focusing on punishment within the United States legal system. Though the law exerts a weak influence on punitive ideologies before punishment occurs, we argue that it effectively coordinates perceptions of individuals who have already been punished. Next, we discuss intergroup conflict, which often co-occurs with disagreements related to punishment and represents a related domain where coordination can be difficult to achieve. Here, we underscore how insights from moral psychology can promote equality via the law. These examples demonstrate how contributions from moral psychology are necessary to understand the connection between social cognition and law.

Keywords: intergroup bias, law, moral cognition, prejudice, punishment

On January 1, 1863, Abraham Lincoln proclaimed freedom for "all persons held as slaves within any State or designated part of a State, the people whereof shall then be in rebellion against the United States." Because this proclamation lacked legal standing in the rebellious states, legal freedom did not come until the ratification of the thirteenth amendment in April 1864. Even then, many fought the establishment of provisions to punish members of one group for attempting to own members of another. One

The authors wish to thank E. Tory Higgins and members of the Social and Moral Cognition lab for helpful comments on this project. This project was made possible through the support of grant \#61080 from the John Templeton Foundation to LH. The opinions expressed in this publication are those of the authors and do not necessarily reflect the views of the John Templeton Foundation. This work has also been supported (in part) by a Visiting Scholar award from the Russell Sage Foundation to LH. Any opinions expressed are those of the authors alone and should not be construed as representing the opinions of the Foundation.

Address correspondence to Larisa Heiphetz, Department of Psychology, Columbia University. 1190 Amsterdam Ave., New York, NY 10027. E-mail: lah2201@columbia.edu.

(c) 2021 Guilford Publications, Inc. 
version of the thirteenth amendment, proposed by Senator Charles Sumner, read that "all persons are equal before the law, so that no person can hold another as a slave"but this was too radical for most other members of Congress. The final version made no mention of equality under the law but did state that involuntary servitude was legal as punishment for a crime. Several states from the former confederacy ratified this version only after issuing notices that their ratification did not grant the federal government the right to create legislation regarding the standing of formerly enslaved people (i.e., according to these states, the federal government could not punish Whites for attempting to continue slavery; Tsesis, 2004). More than 150 years later, the full dream embodied in Sumner's proposed amendment remains to be fulfilled, but at least most United States (US) residents no longer voice open support for human bondage.

The controversy around appropriate consequences for people who try to own their fellow human beings illustrates a broader theme concerning moral cognition. Namely, punishment often elicits controversy, particularly in contexts where the people who receive harm and the people who perpetuate harm belong to different social groups. People often disagree about whether such punishment should exist at all and, if so, who should receive the punishment and how severe it should be. Such disagreement is often demarcated by group membership. With regard to civil rights, for instance, White support lags far behind that of Black people (McRae, 2018; Sokol, 2008).

Such disagreements can present a coordination problem. Here, we join other scholars in conceptualizing a "coordination problem" as the kind of issue that arises when actors experience conflict over what outcome is most desirable (McAdams \& Nadler, $2005,2008)$. Such disputes are commonplace in everyday life. For example, two individuals may wish to have a relaxing afternoon in the same public park; however, one of them wants to relax by quietly reading a book, while the other wants to play loud rock-and-roll music for all to hear. Or, perhaps more consequentially, two people may desire to introduce policies for penal reform. While one wants to increase the length of time people spend in prisons, the other wants to abolish prisons altogether. In other words, under this conceptualization of a coordination problem, the problem arises when people have competing interests. This differs somewhat from a situation in which independent actors make choices that directly impact one another and have entirely compatible interests, such as separately deciding where to meet the others for dinner.

If people disagree about appropriate punishment, how can US society as a whole determine what should happen to people who transgress? Put slightly differently, how can US society coordinate views about people who transgress? Several scholars have proposed that one function of the law is to facilitate coordination and cooperation among individuals even when they disagree (McAdams, 2015; McAdams \& Nadler, 2005, 2008; Nadler, 2017). We build on this model by arguing that the law (here, we focus particularly on US law) is able to do so because it has the power to communicate moral norms, which can, in turn, coordinate moral cognition and behavior.

The central argument of this article is as follows: Because the law can shape people's moral understanding and behavior, it is equipped to resolve coordination issues that are embedded in systems of social cognition. In this way, law can be likened to an arm and its moral influence can be likened to muscle. Without muscle, an arm is just a fleshy appendage, limp and weak. Analogously, without the ability to communicate moral messages and shape moral norms, the law would not have enough strength 
to coordinate human cognition or behavior; it would have no muscle. Thus, findings from moral psychology—the science of people's morally relevant cognition, behavior, and affect-are necessary in order to understand how this coordination occurs.

For two main reasons, we focus on coordination in the contexts of punishment and intergroup relations. First, these areas often elicit controversy that the law must navigate. Second, these areas underscore the idea that coordination can result in both negative and positive consequences. Within the domain of punishment, coordination can impede justice by propagating the view that people who have received legal punishment are irredeemably bad people. This is an example of "negative coordination." However, within the domain of intergroup relations, coordination can promote justice by establishing greater equality among groups. This is an example of "positive coordination." In both types of cases, understanding moral cognition and behavior is necessary in order to understand why the law is able to coordinate at all, whether justly or unjustly. Thus, the sections below discuss how scientific knowledge of morality is a necessary bridge connecting social cognition (e.g., coordination among different people's judgments) and law.

\section{A CASE OF "NEGATIVE COORDINATION": LAW COORDINATES PEOPLE'S VIEWS ABOUT PUNISHMENT}

We begin by reviewing evidence suggesting that views about punishment can be heterogeneous and clarifying how such heterogeneity can lead to disagreement. Our central claim here is that the law is particularly well suited to help coordinate ideas about punishment because it can communicate who deserves moral condemnation. In turn, these moral messages effectively coordinate people's responses to punishment, including their views toward people who have already received punishment. While coordinating views about punishment helps alleviate disagreement (which may be viewed as an ostensibly positive outcome), coordination within this domain has profoundly negative consequences for those whom the law seeks to punish. In this way, coordination within the domain of punishment has net negative consequences because it stymies justice.

\section{HETEROGENEITY IN PUNITIVE IDEOLOGY AS AN EXAMPLE OF NON-COORDINATION}

The desire to punish emerges early in life and persists across development (e.g., Alicke, 1992; Bregant, Wellbery, \& Shaw, 2019; Cushman, Sheketoff, Wharton, \& Carey, 2013; Hamlin, Wynn, Bloom, \& Mahajan, 2011; Heiphetz \& Young, 2014; Kurzban, DeScioli, \& O’Brien, 2007; Nadler, 2012; Nadler \& McDonnell, 2011; Vaish, Missana, \& Tomasello, 2011; Yucel \& Vaish, 2018; Yudkin, Van Bavel, \& Rhodes, 2019). Although nearly all humans make judgments about punishment, some views may vary across different people and groups of people. Of particular relevance to the legal system, Black and White individuals may hold different views regarding appropriate punishment for legal violations (Bobo \& Johnson, 2004; Forman, 2017; Weaver, 2007). Such disagreements may emerge in part because the US legal system metes out punishment inconsistently and disproportionately punishes people who are marginalized on the basis of racial group membership (e.g., Alexander, 2012; Forman, 2017; Harcourt, 2007). 
Compared to their White peers, Black and Latinx people are more likely to experience police surveillance (e.g., Harcourt, 2007) and police use of force (e.g., Trinkner, Kerrison, \& Goff, 2019; Weitzer, 2015). Of course, disagreements about punishment are not solely demarcated by racial group membership and may also emerge between other social groups (e.g., groups identifying with different political parties).

Such non-coordination regarding views of punishment can be detrimental. According to models of procedural justice, punishments delivered by the legal system are perceived as more legitimate when they are perceived as fair (Tyler \& Huo, 2002). If a person's likelihood of being sentenced to particular punishments depends on who is deciding which punishment to deliver, rather than depending solely on the transgression that was committed, the system that delivers these punishments can be perceived as capricious and, therefore, unfair. When people view punishment as unfair, they may be less likely to follow the norms that the legal system tries to establish (Tyler, 2006). In other words, non-coordination regarding views of punishment may predict non-coordination regarding legally relevant behaviors, such as following the law, an ostensibly undesirable outcome. Though non-coordination in and of itself may be undesirable for those who seek to mete out punishment, coordination within this domain is extraordinarily costly for those who receive punishment. We elaborate on the net negative consequences of coordination within the domain of punishment below.

By integrating research demonstrating that (a) ideas about punishment vary across people and (b) punishment must be coordinated in order to be beneficial, it may seem that social cognition (i.e., processes that create different judgments regarding punishment) creates situations ripe for failure. Indeed, such situations can highlight the importance of coordination, as the US legal system could be perceived as more legitimate-and could potentially regulate human behavior even more effectively than it currently does-if views regarding who deserves punishment and what type of punishment they should receive were better coordinated (Tyler, 2006; Tyler \& Huo, 2002). Below, we argue that-despite our social cognition-coordination within the legal domain does indeed occur. More specifically, we argue that such coordination comes about after legal punishment is delivered and has negative consequences for punished individuals.

\section{COORDINATION IN THE DOMAIN OF PUNISHMENT: THE LAW COORDINATES THE VIEW THAT PUNISHED INDIVIDUALS ARE IRREDEEMABLY IMMORAL}

Though the law may not strongly coordinate punitive ideologies before punishment decisions are made, stronger coordination emerges after punishment occurs. Below, we review evidence that the law can signal information about who deserves moral condemnation and punishment. We then draw on past work showing that laws can communicate information about consensus to argue that the moral messages communicated by laws coordinate people's views about punishment (e.g., how to view people who have received punishment). Thus, within the domain of punishment, the coordinating power of current laws within the US context lies not in shaping views concerning what type of punishment people should receive, but in coordinating people's views of those who have already received punishment. 
In the United States, laws coordinate public perceptions in part by communicating negative information about those who have received punishment via the legal system (e.g., Alexander, 2012; Dunlea \& Heiphetz, 2020; Kleinfeld, 2016; Yankah, 2004; also see Bilz, 2016; Bregant, Shaw, \& Kinzler, 2016; Ho, Cushman, Littman, \& Austerweil, 2019, for evidence that punishment is communicative). Consider the widely implemented "three strikes" laws, which stipulate that a third felony conviction warrants a lengthy sentence (Meese, 1994). Such laws, among others, communicate that people who have committed crimes are not just people who have done bad things but are themselves irredeemably bad (Dunlea \& Heiphetz, 2020; Kleinfeld, 2016; Yankah, 2004).

Humans are especially attentive to messages with morally relevant content (Brady, Gantman, \& Van Bavel, 2020). People attend to messages communicated by the law (e.g., Bilz, 2016) and perceive information conveyed by the law to reflect predominant social norms (McAdams, 2015; Nadler, 2017; Tankard \& Paluck, 2016, 2017). To illustrate this point, consider a hypothetical new law that restricts the rights of formerly incarcerated individuals. Given its content, this law may communicate something negative about incarcerated people (e.g., that they deserve punishment but not freedom; Yankah, 2004). Further, this law can communicate that, in general, other community members endorse this view (e.g., a majority of others also agree that incarcerated people do not deserve freedom; Tankard \& Paluck, 2017). If a particular community member already endorses such a position, this new law may lead that individual to think that others favor it as well, which could subsequently reinforce the strength of this preexisting view (Nadler, 2017). Even if a particular individual does not already endorse such a view, perceptions of normativity may instantiate change. Indeed, converging lines of evidence from social cognition and behavioral economics suggest that people often change their behavioral intentions (e.g., Gerber \& Rogers, 2009) as well as their actual behaviors (e.g., Bicchieri \& Mercier, 2014; Cialdini, Reno, \& Kallgren, 1990; Fehr \& Gächter, 2000; Krupka \& Weber, 2013) to conform to norms they perceive to be commonly held. But why might changes in descriptive norms-that is, perceptions of how other people think and behave-lead people to change their behaviors? Insights from moral psychology are needed to help answer this question.

Some theoretical proposals suggest that people incorporate information about both descriptive and moral norms when making judgments (e.g., when evaluating what is normal; Bear \& Knobe, 2017; Wysocki, 2020) and that, in turn, such judgments influence may influence people's behaviors (e.g., Cialdini et al., 1990). This work suggests that people distinctly represent descriptive and moral norms when making certain types of judgments (e.g., normality). However, other programs of research find that the perceived boundary between descriptive and moral norms may be blurry at times. This research suggests that people may glean moral norms (how people should behave) from descriptive norms (how people do behave; Goldring \& Heiphetz, 2020; Lindström, Jangard, Selbing, \& Olsson, 2018; Roberts, Guo, Ho, \& Gelman, 2018). That is, people infer that what is common is also moral. For example, when people perceive that a particular view (e.g., incarcerated people are intrinsically bad and should be punished) is becoming even more normative than it currently is, they may believe that holding such a view is morally "good" or "right." People are highly motivated to be seen as moral (for a review, see Ellemers, van der Toorn, Paunov, \& van Leeuwen, 2019). Therefore, they may be especially willing to behave concordantly with perceived descriptive 
norms (e.g., supporting punitive outcomes; Son, Bhandari, \& FeldmanHall, 2019; Tankard \& Paluck, 2016).

Thus, our proposal is that laws communicate moral messages (e.g., about the moral character of incarcerated people) and that such messages tell people what others in the community collectively think about a given topic (e.g., punishment). That is, such messages announce descriptive norms. People sometimes infer moral norms from descriptive norms; thus, the perceived normativity of these beliefs can influence the extent to which people view that such beliefs are morally good. In turn, people's desire to be seen as moral may drive them to behave in accordance with messages communicated by the law; this desire to be seen as moral may ultimately underlie coordination. In other words, messages communicated by the law are necessary for coordinating people's views of individuals who have received punishment.

\section{APPROACHES TO REDUCING NEGATIVITY TOWARD PUNISHED INDIVIDUALS: INSIGHTS FROM MORAL PSYCHOLOGY}

As previously mentioned, coordination can be desirable for punishers because it makes their actions appear legitimate (e.g., Tyler, 2006; Tyler \& Huo, 2002). However, for those on the receiving end of punishment, such coordination can be undesirable given that the law can communicate that punished individuals and those who care for them are immoral and can never repay their debt to society-a view that is particularly common in the United States (Alexander, 2012; Dunlea \& Heiphetz, 2020; Kleinfeld, 2016; Yankah, 2004). As such, punished individuals may wonder how such negativity can be reduced. Research within moral psychology has begun to address this question.

In one line of work (Heiphetz, 2019), adults learned about two different individuals who were described as "bad." Consistent with the messages communicated via the law, one individual's badness was attributed to internal, immutable causes. The other individual's badness was attributed to social factors. After learning about each person, participants divided five resources between them. Adults allocated fewer resources than would be expected by chance to the individual who was described as inherently bad and, thus, allocated more resources to the individual whose badness was attributed to social factors. This result suggests that messages inconsistent with those communicated by the US legal system (i.e., portraying incarcerated people as redeemable rather than inherently bad) may, at least momentarily, increase positivity toward punished individuals.

Related work more directly examined the extent to which messages can reduce negativity toward people who have had contact with the US legal system (Dunlea \& Heiphetz, 2019). Here, children reported extremely negative attitudes toward people whose incarceration was attributed to internal badness. These attitudes improved slightly when the incarceration was attributed to behavioral factors (e.g., doing something wrong) and improved somewhat more when the incarceration was attributed to societal inequality (e.g., poverty). In a follow-up study, children reported more positive attitudes toward a person whose incarceration was attributed to internal plus societal reasons (e.g., being a bad person and growing up poor) than toward a person whose incarceration was attributed to an internal reason alone or an internal reason plus a behavioral reason (e.g., being a bad person and doing something wrong). This result suggests that providing information about societal inequalities associated with 
incarceration can reduce the negativity associated with the types of messages communicated by US law (i.e., that incarcerated people are inherently bad).

This work is critical in understanding how society can leverage moral psychology to benefit people who have had contact with the legal system. However, interventions such as those suggested above (i.e., teaching children and adults about the societal inequalities that underlie mass incarceration) are aimed at individuals, not society at large. To affect societal representations of punishment, such interventions must be scaled up to the level of the law. Doing so is no small task. However, even incremental changes in US criminal law can begin to change perspectives on punishment.

\section{APPROACHES TO REDUCING NEGATIVITY TOWARD PUNISHED INDIVIDUALS: INSIGHTS FROM LAW}

As a first step, states can work to eliminate "three strikes" laws. These laws often mandate a life sentence after a third felony conviction, licensing the inference that people who have committed multiple crimes can never improve (e.g., Kleinfeld, 2016; Yankah, 2004). Lawmakers in the United States can curb such inferences by borrowing from European criminal law. For instance, in Germany, sentencing guidelines specify punishment "frames" - upper and lower sentence limits—-for given offenses. Under this framework, a person found guilty of theft cannot be imprisoned for more than five years, regardless of prior criminal history. Unlike in the United States, where perpetual punishment for recidivists connotes a permanently "ruined self," punishment in Europe connotes that what people do in the present need not determine who they will be in the future (Kleinfeld, 2016). If laws in the United States change to connote less negativity towards people who have had contact with the legal system (i.e., by signaling that such individuals are not intrinsically immoral, as do laws in some European countries), people living in the United States may change how they think about such individuals.

Change at the level of the law is crucial because, as previously mentioned, the law has unique coordinating power and is well positioned to reduce disagreement with the moral messages it communicates (e.g., McAdams, 2015). Of course, the question of whether repealing extant statutes within US criminal law will help attenuate negativity toward currently and formerly incarcerated individuals is empirical in nature. Future work can directly test this possibility.

\section{A CASE OF "POSITIVE COORDINATION": LAW COORDINATES PEOPLE'S VIEWS ABOUT PREJUDICE}

The section above provided evidence that the law is especially well positioned to coordinate human behavior in the domain of punishment, although such coordination can have unjust consequences. As mentioned at the beginning of this article, disputes (i.e., bouts of non-coordination) regarding punishment often track situations where prejudice and other forms of intergroup negativity are salient. In other words, non-coordination about punitive ideology often occurs in parallel to non-coordination about intergroup attitudes. This observation suggests that human behavior and cognition are also difficult to coordinate in the domain of intergroup relations. Psychologists have long been interested in reducing negativity stemming from intergroup conflict and disagreement (e.g., Cohen \& Insko, 2008). Nevertheless, the field has experienced limited success given 
that prejudice and discrimination continue to be some of humanity's greatest challenges. Here, we argue that law is particularly well suited to help attenuate intergroup conflict because it can signal that such behavior is immoral. That is, we argue that the law can coordinate people's views in a way that promotes positive change. In this way, findings from moral psychology, such as those regarding the influence of moral norms, serve as a necessary link between social cognition (e.g., people's representations of members of different groups) and law (e.g., anti-discrimination efforts). Because the law alters social cognition via morality by communicating that some ways of responding to other people are immoral, understanding moral psychology is necessary in order to fully understand the relation between social cognition and law.

\section{NEGATIVE INTERGROUP RELATIONS AS AN EXAMPLE OF NON-COORDINATION}

Within the first three months of life, infants already attend to the race and gender of different faces (Quinn, Lee, \& Pascalis, 2019). Children report more positive evaluations of members of their own group and the socially dominant group than of outgroup members and members of stigmatized groups (Bigler, Jones, \& Lobliner, 1997; Dunham, Baron, \& Carey, 2011; Heiphetz \& Young, 2019; McGlothlin \& Killen, 2010). Adults automatically encode categories such as race and gender-a rapid process that often occurs without conscious awareness or control (Fiske \& Neuberg, 1990). They may have learned that it is not acceptable to say out loud that they prefer Whites to Blacks, but evidence of stereotyping and prejudice emerges on implicit measures (Kang et al., 2011; Nosek, 2007). These biases manifest in part as a lack of pro-social behavior toward out-groups. In many circumstances, children and adults preferentially share resources with in-group members (Duclos \& Barasch, 2014; Dunham et al., 2011; McGuire, Rizzo, Killen, \& Rutland, 2018) and demonstrate more willingness to help in-group versus out-group members (Gaertner, Dovidio, \& Johnson, 1982; Levine, Prosser, Evans, \& Reicher, 2005; Sierksma, 2018). Thus, research in social cognition suggests that the tendency to hold differential views of in-group and out-group members emerges early in life and is tenacious throughout development. In other words, people's views regarding specific social groups are not coordinated with one another, as members of different social groups favor members of their own group.

Notably, bias against members of stigmatized groups occurs in a range of consequential settings, including the US legal system. One legal process that has received a considerable amount of attention within psychology is jury selection (e.g., Norton, Sommers, \& Brauner, 2007; Sommers \& Norton, 2007, 2008). The sixth amendment guarantees the right to a trial with a fair, impartial jury. Ostensibly, one way to ensure this outcome is through peremptory challenges, the process in which an attorney can object to a proposed juror. Support for peremptory challenges rests on the assumption that attorneys can detect biased jurors and that, upon removing such individuals, the promise made by the sixth amendment will be upheld. Nevertheless, empirical evidence does not support the idea that jury selection decisions are impartial. For example, in one study (Sommers \& Norton, 2007), participants were more likely to challenge Black versus White prospective jurors. Strikingly, this bias was stronger among trial attorneys than college students or law students. 
Consistent with the idea discussed in the introduction that perceptions regarding punishment and intergroup interactions are often intertwined, the negative consequences of racial bias also accrue to those whom the law seeks to punish. Black people endure worse outcomes than White people at all stages of legal involvement: they are more likely to experience arrest and negative interactions with police (Brunson, 2007; Stevens \& Morash, 2015), face bias from lawyers and jurors (Mitchell, Haw, Pfeifer, \& Meissner, 2005; Richardson \& Goff, 2013; Sommers \& Ellsworth, 2000), and spend time in jail and prison (Alexander, 2012). Moreover, individuals with stereotypically Black features are more likely to receive the death penalty than individuals who look less stereotypically Black (Eberhardt, Davies, Purdie-Vaughns, \& Johnson, 2006). Disadvantage also accrues on the basis of gender (Rathbone, 2007) and socioeconomic status (Eubanks, 2018), among other group memberships. Thus, non-coordination on the basis of group membership can play an important role in the US legal system.

\section{COORDINATION IN THE DOMAIN OF INTERGROUP RELATIONS: THE LAW COORDINATES THE VIEW THAT PREJUDICE IS IMMORAL}

Although prejudice and discrimination are pervasive within the US legal system, research from moral psychology offers unique insight into how the law can work to coordinate people's views regarding the immorality of prejudice, ultimately reducing such negative outcomes. In other words, moral psychology clarifies how social cognition, including that of legal actors, can be altered to better achieve the law's antidiscrimination goals.

People sometimes turn to the law to tell them what is (im)moral (e.g., Berkowitz \& Walker, 1967; Tyler, 2006). Thus, one way to reduce bias is to implement and enforce laws that communicate that bias is morally wrong. In one study demonstrating the influence of law on moral cognition (Berkowitz \& Walker, 1967), adults rated the immorality of several behaviors. Next, participants learned that some behaviors were legal whereas others were illegal. Crucially, participants viewed behaviors as more immoral after learning about their illegality. The results of this study provide initial evidence that the law can coordinate people's views about the moral valence of particular behaviors. Further supporting the idea that the law can be a useful tool with which to reduce bias, more recent work has shown that anti-gay bias in a given state decreased after that state legalized same-sex marriage (Ofosu, Chambers, Chen, \& Hehman, 2019). Put slightly differently, the results of this work suggest that the law can coordinate people's views in a way that decreases bias. Taken together, these studies suggest that implementing and enforcing anti-discrimination laws can reduce the likelihood that people will act in a biased manner by increasing public support for the view that bias and other instances of intergroup negativity are immoral.

Studies of moral cognition offer additional insights into how passing and enforcing a specific law can coordinate views pertinent to intergroup relations and ultimately affect positive social change. In a line of work demonstrating that legal changes may shift perceived norms, Tankard and Paluck (2017) manipulated participants' beliefs about the likelihood of the then-upcoming Supreme Court ruling regarding same-sex marriage (Obergefell $v$. Hodges, 2015). Half of the participants read that the Supreme Court was likely to rule in favor of fully legalizing same-sex marriage, whereas the 
other half read that such an outcome was unlikely. Participants in the favorable ruling condition were more likely than those in the unfavorable ruling condition to report that Americans collectively support same-sex marriage. A longitudinal study further showed that the actual Obergefell $v$. Hodges ruling in favor of same-sex marriage was associated with an increase in perceived norms supporting same-sex marriage. This work therefore suggests that anti-discrimination laws (e.g., those ensuring fundamental human rights to same-sex couples) can effectively coordinate people's views about norms (e.g., support for same-sex marriage).

Research from moral psychology is necessary to understand why changes in law alter social cognition. As previously discussed, people often infer that what is normative also should be normative, meaning that what is common is moral (e.g., Lindström et al., 2018; Roberts et al., 2018). Because people are motivated to be seen as moral (e.g., Ellemers et al., 2019), they may be especially willing to behave concordantly with perceived descriptive norms (e.g., refraining from discriminating against same-sex couples; Tankard \& Paluck, 2016), ostensibly because doing so puts them in the moral majority. Understanding this aspect of moral psychology clarifies how coordinating views about perceived norms within the legal system can alter social cognition (e.g., attenuating negativity toward stigmatized groups).

\section{ADDITIONAL APPROACHES TO REDUCING PREJUDICE: INSIGHTS FROM MORAL PSYCHOLOGY}

Moral psychology offers additional insights for increasing moral behavior broadly construed, which are relevant to prejudice reduction efforts if one conceives of prejudice as immoral. One such line of work highlights the importance of linking behavior to identity. This can be done subtly, using noun labels. The logic here is that using a noun connects a particular behavior to who a person is, whereas using other linguistic forms can make the behavior appear more transient (Markman, 1989). In line with this reasoning, adults are less likely to cheat when others ask them to "not be a cheater" rather than when others ask them to "not cheat" (Bryan, Adams, \& Monin, 2013). Similarly, children are more likely to help others when they hear about being "a helper" than when they are asked "to help" (Bryan, Master, \& Walton, 2014), and participants are less likely to litter when they are labeled as "litter-conscious" than when they are asked "not to litter" (Miller, Brickman, \& Bolen, 1975). Importantly, this latter effect remained even seven weeks after the initial manipulation. This finding highlights the potential for noun-labeling interventions to effectively coordinate people's behavior (a) outside of a lab setting and (b) in a way that promotes positive outcomes over an extended period of time. Applying this logic to the legal context, jury instructions containing phrases like "remember to be an egalitarian person" or "do not be a bigot" could help to reduce juror bias.

A separate line of work in moral psychology highlights the role that moral realism plays in pro-social action. Moral realism refers to the notion that moral beliefs can be objectively true or false, akin to factual beliefs, and that if two people disagree about a moral view, only one person can be correct (Heiphetz \& Young, 2017). Encouraging people to adopt a realist perspective increases charitable donations (Young \& Durwin, 2013) and reduces cheating (Rai \& Holyoak, 2013). In the legal context, it may be beneficial to establish coordination (i.e., public agreement) around the idea that prejudice 
is morally wrong while also leading people to adopt a realist mindset. For instance, using the methodology from Young and Durwin's (2013) study, jurors could be asked whether they agree that "some things are just morally right or wrong, good or bad, wherever you happen to be from in the world" and then, immediately afterwards, whether they think that prejudice is wrong. Group dynamics can lead individual jurors to conform to the opinion expressed by the majority during jury deliberation (e.g., Son et al., 2019), and there is some evidence that group discussion can exacerbate bias in the jury deliberation process (e.g., Hulbert, Parks, Chen, Nam, \& Davis, 1999). As such, it is possible that the prejudiced opinion of one juror may "spread" to other jurors during the jury deliberation process. However, completing the moral realism intervention described here as part of the jury instruction procedure, before deliberations begin, may mitigate against this effect. In other words, jurors who have been led to view prejudice as objectively wrong may be more likely to behave pro-socially toward the defendant and to resist the "spread" of bias against that defendant.

Evidence from moral psychology suggests that individual-level interventions (e.g., linking desirable behaviors to identity, encouraging people to adopt realist mindsets when making legal decisions) may effectively coordinate the view that bias and discrimination are immoral, thus reducing such negative outcomes. However, for completeness, we also review evidence from a smaller set of studies suggesting potential caveats to these interventions. For instance, some studies suggest that helping may license negative inferences about members of the group that received help, as children and adults sometimes perceive individuals who receive help as less competent than individuals who do not (Nadler \& Chernyak-Hai, 2014; Sierksma \& Shutts, 2020). Relatedly, statements expressing equality (e.g., "naturalized citizens are just as American as natural born citizens") can inadvertently perpetuate harmful stereotypes (e.g., people may infer that natural born citizens are indeed "more American" than naturalized citizens, Chestnut \& Markman, 2018). Therefore, the identity-linked interventions recommended above may be most effective if they focus jurors' attention on themselves rather than on defendants. For instance, asking jurors to "be an egalitarian person," as suggested above, may be more effective than encouraging jurors to help defendants by rendering an egalitarian verdict or reminding them that stereotypes about defendants are inaccurate.

Important questions may also arise about the external validity of the types of interventions proposed here. Bias-reduction interventions sometimes have short-lasting effects, some lasting less than a day (e.g., Lai et al., 2016). The positive outcomes brought about by the aforementioned interventions may follow a similar pattern (though see Miller et al., 1975, for a notable exception). To ensure efficacy, one possibility is to administer the intervention immediately before a crucial decision point in the legal process (e.g., immediately before jurors begin deliberations or render a verdict; Carter, Onyeador, \& Lewis, 2020). Moreover, the extent to which the effects demonstrated by interventions conducted in tightly controlled experimental settings replicate in other contexts is unclear. Some effects of identity-linked language are relatively small (e.g., Bryan et al., 2013). Therefore, it is possible that interventions-at least those using noun labels to reduce immoral behavior-may exert a weaker effect on behavior in everyday contexts where situations are less tightly controlled. Nevertheless, some evidence points to the possible efficaciousness of such interventions. For instance, reminding US citizens to "be a voter" increased actual voter turnout in two statewide elections (Bryan, Walton, Rogers, \& Dweck, 2011), demonstrating the efficacy of identity-linked language 
outside the lab. Additional work remains to be done to clarify how linking morally relevant behavior to personal identity might alter behavior outside of a lab context, including within the legal system.

\section{ADDITIONAL APPROACHES TO REDUCING PREJUDICE: INSIGHTS FROM LAW}

The individual-level interventions proposed above form only one component of an effective strategy to promote equality before the law. Many issues of discrimination are structural in nature, and individual-level interventions are not sufficient to eradicate them. The most effective solutions to societal problems occur at the societal level. One such solution is for the legal system to become more astute regarding which behaviors it criminalizes and how it enforces its statutes. For example, removing federal criminal penalties for marijuana possession would reduce the need to fight juror discrimination in those cases, as people found in possession of marijuana would no longer be tried in courts. Such an approach could be particularly helpful in reducing group-based bias in the legal system, as Black and Latinx people are currently more likely to become involved in this system for drug possession despite using drugs at rates similar to those of Whites (Alexander, 2012; Forman, 2017). As another example, and related to the discussion above regarding the possible influence of anti-discrimination laws on reductions in discriminatory behavior, the legal system could add and enforce additional penalties against group-based discrimination. Such steps could include reinstating legislation barring racial discrimination in voting (i.e., the Voting Rights Act), adopting protections for transgender individuals, and ensuring that people are not barred from entering the United States on the basis of religion and other protected group memberships, among other possibilities.

The main point here is that structural change does not simply involve adding or removing penalties but rather discerning which actions should be penalized and which should not. Because the contributions of moral psychology constitute a main focus of this article, our emphasis has been on specific interventions backed by evidence from this field-and because psychology as a field is designed to focus on the individual psyche, these interventions work to coordinate individuals' views in hopes of reducing bias on a group level. Such interventions can be beneficial, particularly when their implementation is sensitive to their limitations (e.g., when they are administered immediately before an important decision point in recognition of the fact that effects may wear off soon after participants complete the intervention). Indeed, such interventions may be particularly necessary because changing legislation takes time and legislator buy-in. Individual-level interventions can provide needed relief while waiting for structural-level changes, but the root of negative intergroup relations runs deeper than bias stemming from individual and interpersonal processes. Thus, individual-level interventions should precede and potentially be used in combination with-not instead of-legislative reform and other structural solutions. Of course, reducing such negative outcomes is desirable in the legal context given that it is a context where lives hang in the balance; nevertheless, the benefits conferred by the interventions highlighted in this section may also generalize to domains outside the legal context. 


\section{CONCLUSIONS}

Using the example of the US legal system, we argued that law can be an effective means to coordinate diverse views regarding punishment and intergroup relations. In so doing, we showed how coordination can impede justice (e.g., by promoting public consensus that the people the law punishes are irredeemably bad) as well as advance justice (e.g., by promoting anti-discrimination norms). Such coordination relies on moral cognition and behavior. For instance, law shapes social cognition both by communicating that people who have had contact with the legal system are immoral and by convincing the public, sometimes over long periods of time, that discrimination is immoral. Insights from moral psychology can also connect social cognition and law by suggesting effective interventions to further the law's egalitarian aims. Ultimately, findings from moral psychology—together with structural reform-can help create a world where all persons are indeed equal before the law.

\section{REFERENCES}

Alexander, M. (2012). The new Jim Crow: Mass incarceration in the age of colorblindness. New York: New Press.

Alicke, M. D. (1992). Culpable causation. Journal of Personality and Social Psychology, 63, 368-378. https://doi.org/10.1037/ 0022-3514.63.3.368

Bear, A., \& Knobe, J. (2017). Normality: Part descriptive, part prescriptive. Cognition, 167, 25-37. https: / / doi.org/10.1016 /j.cognition.2016.10.024

Berkowitz, L., \& Walker, N. (1967). Laws and moral judgments. Sociometry, 30, 410422. https: / / doi.org/10.2307/2786186

Bicchieri, C., \& Mercier, H. (2014). Norms and beliefs: How change occurs. In M. Xenitidou \& B. Edmonds (Eds.), The complexity of social norms (pp. 37-54). Basel: Springer International.

Bigler, R. S., Jones, L. C., \& Lobliner, D. B. (1997). Social categorization and the formation of intergroup attitudes in children. Child Development, 68, 530-543. https://doi .org/10.1111/j.1467-8624.1997.tb01956.x

Bilz, K. (2016). Testing the expressive theory of punishment. Journal of Empirical Legal Studies, 13, 358-392. https:/ / doi.org/10 $.1111 /$ jels. 12118

Bobo, L. D., \& Johnson, D. (2004). A taste for punishment: Black and white Americans' views on the death penalty and the war on drugs. DuBois Review: Social Science Research on Race, 151-180. https: / / doi.org/10.10170S1742058X04040081
Brady, W. J., Gantman, A. P., \& Van Bavel, J. J. (2020). Attentional capture helps explain why moral and emotional content go viral. Journal of Experimental Psychology: General, 149, 746-756. https:// doi.org/10.1037/xge0000673

Bregant, J., Shaw, A., \& Kinzler, K. D. (2016). Intuitive jurisprudence: Early reasoning about the functions of punishment. Journal of Empirical Legal Studies, 13, 693-717. https://doi.org/10.1111/jels.12130

Bregant, J., Wellbery, I., \& Shaw, A. (2019). Crime but not punishment? Children are more lenient toward rule-breaking when the "spirit of the law" is unbroken. Journal of Experimental Child Psychology, 178, 266-282. https://doi.org/ 10.1016/j.jecp.2018.09.019

Brunson, R. K. (2007). “Police don't like Black people": African American young men's accumulated police experiences. Criminology \& Public Policy, 6, 71-101. https://doi:.org/10.1111/j.1745-9133 .2007.00423.x

Bryan, C. J., Adams, G. S., \& Monin, B. (2013). When cheating would make you a cheater: Implicating the self prevents unethical behavior. Journal of Experimental Psychology: General, 142, 1001-1005. https://doi.org/10.1037/a0030655

Bryan, C. J., Master, A., \& Walton, G. M. (2014). "Helping" versus "being a helper": Invoking the self to increase helping behavior in young children. Child 
Development, 85, 1836-1842. https:/ / doi. org/ 10.1111/cdev.12244

Bryan, C. J., Walton, G. M., Rogers, T., \& Dweck, C. S. (2011). Motivating voter turnout by invoking the self. Proceedings of the National Academy of Sciences, 108, 12653-12656. https://doi.org/10.1073/ pnas. 1103343108

Carter, E. R., Onyeador, I. N., \& Lewis, N. A., Jr. (2020). Developing and delivering effective anti-bias training: Challenges and recommendations. Behavioral Science and Policy, 6, 57-70. https://doi.org/10.1353 /bsp.2020.0005

Chestnut, E. K., \& Markman, E. M. (2018). "Girls are as good as boys at math" implies that boys are probably better: A study of expressions of gender equality. Cognitive Science, 42, 2229-2249. https: / / doi.org10.1111/cogs.12637

Cialdini, R. B., Reno, R. R., \& Kallgren, C. A. (1990). A focus theory of normative conduct: Recycling the concept of norms to reduce littering in public places. Journal of Personality and Social Psychology, 58, 10151026. https://doi.org/10.1111/cogs.12637

Cohen, T. R., \& Insko, C. A. (2008). War and peace: Possible approaches to reducing intergroup conflict. Perspectives on Psychological Science, 3, 87-93. https://doi .org/10.1111/j.1745-6916.2008.00066.x

Cushman, F., Sheketoff, R., Wharton, S., \& Carey, S. (2013). The development of intent-based moral judgment. Cognition, 127, 6-21. https://doi.org/10.1016 /j.cognition.2012.11.008

Duclos, R., \& Barasch, A. (2014). Prosocial behavior in intergroup relations: How donor self-construal and recipient groupmembership shape generosity. Journal of Consumer Research, 41, 93-108. https:/ / doi.org/10.1086/674976

Dunham, Y., Baron, A. S., \& Carey, S. (2011). Consequences of "minimal" group affiliations in children. Child Development, 82, 793-811. https://doi.org/10.1111/j.1467 -8624.2011.01577.x

Dunlea, J. P., \& Heiphetz, L. (2019). Making the best of a bad situation: Examining the consequences of explanations highlighting societal inequality. Poster presented at the biennial meeting of the Cognitive Development Society. Louisville, Kentucky.
Dunlea, J. P., \& Heiphetz, L. (2020). Children's and adults' understanding of punishment and the criminal justice system. Journal of Experimental Social Psychology, 87, 103913. https://doi.org/10.1016 /j.jesp.2019.103913

Eberhardt, J. L., Davies, P. G., Purdie-Vaughns, V. J., \& Johnson, S. L. (2006). Looking deathworthy: Perceived stereotypicality of Black defendants predicts capitalsentencing outcomes. Psychological Science, 17, 383-386. https://doi.org/10 $.1111 /$ j.1467-9280.2006.01716.x

Ellemers, N., van der Toorn, J., Paunov, Y., \& van Leeuwen, T. (2019). The psychology of morality: A review and analysis of empirical studies published from 1940 through 2017. Personality and Social Psychology Review, 23, 332-366. https: / / doi .org/10.1177/1088868318811759

Eubanks, V. (2018). Automating inequality: How high-tech tools profile, police, and punish the poor. New York: St. Martin's Press.

Fehr, E., \& Gächter, S. (2000). Cooperation and punishment in public goods experiments. American Economic Review, 90, 980-994. https://doi.org/10.1257/aer.90 .4 .980

Fiske, S. T., \& Neuberg, S. L. (1990). A continuum of impression formation, from category-based to individuating processes: Influences of information and motivation on attention and interpretation. In M. P. Zanna (Ed.), Advances in experimental social psychology (pp. 1-74). San Diego, CA: Academic Press.

Forman, J., Jr. (2017). Locking up our own: Crime and punishment in Black America. New York: Farrar, Straus and Giroux.

Gaertner, S. L., Dovidio, J. F., \& Johnson, G. (1982). Race of victim, nonresponsive bystanders, and helping behavior. Journal of Social Psychology, 117, 69-77. https: / / doi.org/10.1080/00224545 .1982 .9713409

Gerber, A. S., \& Rogers, T. (2009). Descriptive social norms and motivation to vote: Everybody's voting and so should you. Journal of Politics, 71, 178-191. https:// doi.org/10.1017/S0022381608090117

Goldring, M. R., \& Heiphetz, L. (2020). Sensitivity to ingroup and outgroup norms in the association between commonality and morality. Journal of Experimental 
Social Psychology, 91, 104025. https:// doi.org/10.1016/j.jesp.2020.104025

Hamlin, J. K., Wynn, K., Bloom, P., \& Mahajan, N. (2011). How infants and toddlers react to antisocial others. Proceedings of the National Academy of Sciences, 108, 19931-19936. https://doi.org/10.1073/ pnas. 1110306108

Harcourt, B. E. (2007). Against prediction: Profiling, policing, and punishing in an actuarial age. Chicago: University of Chicago Press.

Heiphetz, L. (2019). Moral essentialism and generosity among children and adults. Journal of Experimental Psychology: General, 148, 2077-2090. https:/ / doi.org/10 $.1037 /$ xge0000587

Heiphetz, L., \& Young, L. (2014). A social cognitive developmental perspective on moral judgment. Behaviour, 151, 315335. https:/ / doi.org/10.1163/1568539X $-00003131$

Heiphetz, L., \& Young, L. L. (2017). Can only one person be right? The development of objectivism and social preferences regarding widely shared and controversial moral beliefs. Cognition, 167, 78-90. https://doi.org/10.1016/j.cognition .2016.05.014

Heiphetz, L., \& Young, L. L. (2019). Children's and adults' affectionate generosity toward members of different religious groups. American Behavioral Scientist, 63, 1910-1937. https://doi.org/10.1177/ 0002764219850870

Ho, M. K., Cushman, F., Littman, M. L., \& Austerweil, J. L. (2019). People teach with rewards and punishments as communication, not reinforcements. Journal of Experimental Psychology: General, 148, 520-549. https://doi.org/10.1037/xge 0000569

Hulbert, L. G., Parks, C. D., Chen, X., Nam, K., \& Davis, J. H. (1999). The plaintiff bias in mock civil jury decision making: Consensus requirements, information format and amount of consensus. Group Processes E Intergroup Relations, 2, 59-77. https://doi.org/10.1177/13684302 99021005

Kang, J., Bennett, M., Carbado, D., Casey, P., Dasgupta, N., Faigman, D., Godsil, R., Greenwald, A. G., Levinson, J., \& Mnookin, J. (2011). Implicit bias in the courtroom. UCLA Law Review, 59, $1124-1187$.

Kleinfeld, J. (2016). Two cultures of punishment. Stanford Law Review, 68, 933-1036.

Krupka, E. L., \& Weber, R. A. (2013). Identifying social norms using coordination games: Why does dictator game sharing vary? Journal of the European Economic Association, 11, 495-524. https:/ / doi.org /10.1111/jeea.12006

Kurzban, R., DeScioli, P., \& O'Brien, E. (2007). Audience effects on moralistic punishment. Evolution and Human Behavior, 28, 75-84. https:/ / doi.org/10.1016/j.evolh umbehav.2006.06.001

Lai, C. K., Skinner, A. L., Cooley, E., Murrar, S., Brauser, M., .. \& \& Nosek, B. A. (2016). Reducing implicit racial preferences: II. Intervention effectiveness across time. Journal of Experimental Psychology: General, 145, 1001-1016. https://doi.org /10.1037/xge0000179

Levine, M., Prosser, A., Evans, D., \& Reicher, S. (2005). Identity and emergency intervention: How social group membership and inclusiveness of group boundaries shape helping behavior. Personality and Social Psychology Bulletin, 31, 443-453. https: / / doi.org/10.1177/0146167204271651

Lindström, B., Jangard, S., Selbing, I., \& Olsson, A. (2018). The role of a "common is moral" heuristic in the stability and change of moral norms. Journal of Experimental Psychology: General, 147, 228-242. https: / /doi.org/10.1037/xge0000365

Markman, E. M. (1989). Categorization and naming in children. Cambridge, MA: MIT Press.

McAdams, R. H. (2015). The expressive powers of law: Theories and limits. Cambridge, MA: Harvard University Press.

McAdams, R. H., \& Nadler, J. (2005). Testing the focal point theory of legal compliance: The effect of third-party expression in an experimental hawk/dove game. Journal of Empirical Legal Studies, 2, 87-123. https://doi.org/10.1111/j.1740 $-1461.2005 .00032 . x$

McAdams, R. H., \& Nadler, J. (2008). Coordinating in the shadow of the law: Two contextualized tests of the focal point theory of legal compliance. Law $\mathcal{E}$ Society Review, 42, 865-898. https://doi.org /10.1111/j.1540-5893.2008.00361.x 
McGlothlin, H., \& Killen, M. (2010). How social experience is related to children's intergroup attitudes. European Journal of Social Psychology, 40, 625-634. https:// doi.org/10.1002/ejsp.733

McGuire, L., Rizzo, M. T., Killen, M., \& Rutland, A. (2018). The development of intergroup resource allocation: The role of cooperative and competitive in-group norms. Developmental Psychology, 54, 1499-1506. https://doi.org/10.1037/ dev0000535

McRae, E. G. (2018). Mothers of massive resistance: White women and the politics of White supremacy. New York: Oxford University Press.

Meese, E. (1994). Three-strikes laws punish and protect. Federal Sentencing Reporter, 7, 58-60.

Miller, R. L., Brickman, P., \& Bolen, D. (1975). Attribution versus persuasion as a means for modifying behavior. Journal of Personality and Social Psychology, 31, 430441. https:/ / doi.org/10.1037/h0076539

Mitchell, T. L., Haw, R. M., Pfeifer, J. E., \& Meissner, C. A. (2005). Racial bias in mock juror decision-making: A meta-analytic review of defendant treatment. Law and Human Behavior, 29, 621-637. https:// doi.org/10.1007/s10979-005-8122-9

Nadler, J. (2012). Blaming as a social process: The influence of character and moral emotion on blame. Law and Contemporary Problems, 75, 1-31.

Nadler, J. (2017). Expressive law, social norms, and social groups. Law $\mathcal{E}$ Social Inquiry, 42, 60-75. https://doi.org/10 $.1111 / 1$ si.12279

Nadler, A., \& Chernyak-Hai, L. (2014). Helping them stay where they are: Status effects on dependency/autonomy-oriented helping. Journal of Personality and Social Psychology, 106, 58-72. https://doi.org /10.1037/a0034152

Nadler, J., \& McDonnell, M. H. (2011). Moral character, motive, and the psychology of blame.Cornell Law Review, 97, 255-304.

Norton, M. I., Sommers, S. R., \& Brauner, S. (2007). Bias in jury selection: Justifying prohibited peremptory challenges. Journal of Behavioral Decision Making, 20, 467-479. https://doi.org/10.1002/bdm .571

Nosek, B. A. (2007). Implicit-explicit relations. Current Directions in Psychological
Science, 16, 65-69. https://doi.org/10 $.1111 / \mathrm{j} .1467-8721.2007 .00477 . x$

Obergefell v. Hodges, 135 S. Ct. 2584 (2015).

Ofosu, E. K., Chambers, M. K., Chen, J. M., \& Hehman, E. (2019). Same-sex marriage legalization associated with reduced implicit and explicit antigay bias. Proceedings of the National Academy of Sciences, 116, 8846-8851. https://doi.org/ $10.1073 /$ pnas. 1806000116

Quinn, P. C., Lee, K., \& Pascalis, O. (2019). Face processing in infancy and beyond: The case of social categories. Annual Review of Psychology, 70, 165-189. https://doi. org/10.1146/annurev-psych-010418 $-102753$

Rai, T. S., \& Holyoak, K. J. (2013). Exposure to moral relativism compromises moral behavior. Journal of Experimental Social Psychology, 49, 995-1001. https://doi .org/10.1016/j.jesp.2013.06.008

Rathbone, C. (2007). A world apart: Women, prison, and life behind bars. New York: Random House.

Richardson, L. S., \& Goff, P. A. (2013). Implicit racial bias in public defender triage. Yale Law Journal, 122, 2626-2649.

Roberts, S. O., Guo, C., Ho, A. K., \& Gelman, S. A. (2018). Children's descriptive-toprescriptive tendency replicates (and varies) cross-culturally: Evidence from China. Journal of Experimental Child Psychology, 165, 148-160. https://doi.org /10.1016/j.jecp.2017.03.018

Sierksma, J. (2018). Costs of helping only influence children's intention to help ethnic out-group peers. Journal of Experimental Child Psychology, 173, 85-99. https:// doi.org/10.1016/j.jecp.2018.03.016

Sierksma, J., \& Shutts, K. (2020). When helping hurts: Children think groups that receive help are less smart. Child Development, 91, 715-723. https://doi.org/10 $.1111 /$ cdev.13351

Sokol, J. (2008). There goes my everything: White Southerners in the age of civil rights, 19451975. New York: Vintage Books.

Sommers, S. R., \& Ellsworth, P. C. (2000). Race in the courtroom: Perceptions of guilt and dispositional attributions. Personality and Social Psychology Bulletin, 26, 1367-1379. https://doi.org/10.1177/ 0146167200263005

Sommers,S.R., \&Norton,M.I.(2007). Race-based judgments, race-neutral justifications: 
Experimental examination of peremptory use and the Batson challenge procedure. Law and Human Behavior, 31, 261273. https://doi.org/10.1007/s10979 -006-9048-6

Sommers, S. R., \& Norton, M. I. (2008). Race and jury selection: Psychological perspectives on the peremptory challenge debate. American Psychologist, 63, 527-539. https://doi.org/10.1037/0003 -066X.63.6.527

Son, J. Y., Bhandari, A., \& FeldmanHall, O. (2019). Crowdsourcing punishment: Individuals reference group preferences to inform their own punitive decisions. Scientific Reports, 9, 1-15. https://doi .org/10.1038/s41598-019-48050-2

Stevens, T., \& Morash, M. (2015). Racial/ethnic disparities in boys' probability of arrest and court actions in 1980 and 2000: The disproportionate impact of "getting tough" on crime. Youth Violence and Juvenile Justice, 13, 77-95. https://doi.org/ $10.1177 / 1541204013515280$

Tankard, M. E., \& Paluck, E. L. (2016). Norm perception as a vehicle for social change. Social Issues and Policy Review, 10, 181-211. https://doi.org/10 $.1111 /$ sipr.12022

Tankard, M. E., \& Paluck, E. L. (2017). The effect of a Supreme Court decision regarding gay marriage on social norms and personal attitudes. Psychological Science, 28, 1334-1344. https://doi .org/10.1177/0956797617709594

Trinkner, R., Kerrison, E. M., \& Goff, P. A. (2019). The force of fear: Police stereotype threat, self-legitimacy, and support for excessive force. Law and Human Behavior, 43, 421-435. https://doi.org/ $10.1037 /$ lhb0000339

Tsesis, A. (2004). The thirteenth amendment and American freedom: A legal history. New York: New York University Press.
Tyler, T. R. (2006). Why people obey the law. Princeton, NJ: Princeton University Press.

Tyler, T. R., \& Huo, Y. J. (2002). Trust in the law: Encouraging public cooperation with the police and courts. New York: Russell Sage Foundation.

Vaish, A., Missana, M., \& Tomasello, M. (2011). Three-year-old children intervene in third-party moral transgressions. British Journal of Developmental Psychology, 29, 124-130. https://doi.org/10.1348/0261 $51010 \times 532888$

Weaver, V. M. (2007). Frontlash: Race and the development of punitive crime policy. Studies in American Political Development, 21, 230-265. https://doi.org/10 $.1017 /$ S0898588X07000211

Weitzer, R. (2015). American policing under fire: Misconduct and reform. Society, 52, 475-480. https://doi.org/10.1007/s12115 $-015-9931-1$

Wysocki, T. (2020). Normality: A two-faced concept. Review of Philosophy and Psychology, 1-28. https://doi.org/10.1007/ s13164-020-00463-z

Yankah, E. N. (2004). Good guys and bad guys: Punishing character, equality and the irrelevance of moral character to criminal punishment. Cardozo Law Review, 25, 1019-1032.

Young, L., \& Durwin, A. J. (2013). Moral realism as moral motivation: The impact of meta-ethics on everyday decisionmaking. Journal of Experimental Social Psychology, 49, 302-306. https://doi.org /10 .1016/j.jesp.2012.11.013

Yucel, M., \& Vaish, A. (2018). Young children tattle to enforce moral norms. Social Development, 27, 924-936. https://doi .org/10.1111/sode.12290

Yudkin, D. A., Van Bavel, J. J., \& Rhodes, M. (2019). Young children police group members at personal cost. Journal of Experimental Psychology: General, 149, 182-191. https://doi.org/10.1037/xge0000613 